\title{
Bağ Kirişlerinin Göçme Olasılıklarının Monte Carlo Simülasyonu ile Belirlenmesi
}

\author{
Bilge DORAN ${ }^{* 1}$, Sema ALACALI ${ }^{1}$
}

${ }^{1}$ Yıldız Teknik Üniversitesi, İnşaat Fakültesi, İnşaat Müh. Bölümü, 34220, İstanbul

(Alınıș / Received: 01.02.2016, Kabul / Accepted: 16.11.2016, Online Yayınlanma / Published Online: 09.01.2017)

Anahtar Kelimeler Boşluklu perdeler, Bağ kirişi katkı oranı, Rijitlik düzeltme katsayısı, Göçme olasılığı, Monte Carlo simülasyonu
Özet: Yatay yükler bağ kirişlerinde eğilme ve beraberinde önemli oranda kesme gerilmelerine neden olduğu için, boşluklu perdeli sistemlerin yapısal davranıșları bağ kirişlerinin geometrik, mekanik özellikleri ve bağ kiriși katkı oranı $(r)$ ile yakından alakalı olan davranışlarından oldukça fazla etkilenmektedir. $\mathrm{Bu}$ nedenle, $r$-değerleri boșluklu perdeli sistemlerin doğrusal olmayan hesabında önemli bir parametre olarak düşünülebilir. Bu çalışmada " $r$ " değerlerini belirlemek amacıyla uygulamada sıkça karşılaşılan geometriye sahip yeterli sayıda boşluklu perdeli sistemler dikkate alınarak bağ kirişi katkı oranları genişletilmiş çubuk teorisi yardımı ile ifade edilmiş ve Monte Carlo simülasyonu ile sözkonusu bağ kirişlerin göçme olasılıkları hesaplanmıştır.

\section{The Failure Probability of The Coupling Beams with Monte Carlo Simulation}

\begin{abstract}
Keywords
Coupled shear walls,

Coupling ratio, Stiffness modification factor,

Failure probability, Monte Carlo simulation

Abstract: Since lateral loads cause bending with high shear stresses in coupling beams, the structural behavior of a coupled shear walls is greatly affected by the behavior of the coupling beams which depends on its geometrical, mechanical properties and also coupling ratio $(r)$. The value of $r$ considered to be one of the major issues in nonlinear analysis in coupled shear walls represents the proportion of overturning moment resisted by the coupling action. In order to evaluate the $r$-values by using magnified beam algorithm, an adequate number of coupled shear walls having several geometries commonly used in construction were considered and then failure probabilities of coupling beams were calculated using Monte Carlo simulation.
\end{abstract}




\section{Introduction}

In mid and high rise reinforced concrete (R/C) buildings, shear wall (SW) and coupled shear wall (CSW) systems are usually used effectively to provide the required stiffness and strength for earthquake loadings. The structural behavior of a CSW is greatly affected by the behavior of the coupling beams, since the lateral loads such as earthquake cause bending with high shear stresses in coupling beams (Figure 1.)

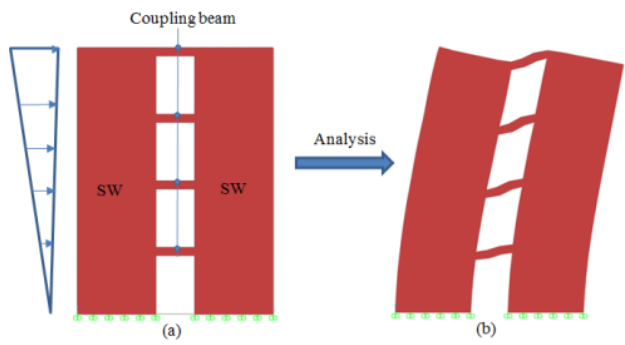

Figure 1. A typical coupled shear wall (a) Loading condition (b) Deformed shape

There are several modelling techniques (such as three dimensional finite solid modelling and two dimensional modelling) suggested for the evaluation of the elastic behavior of the CSWs $[1,2,3,4,5,6,7,8,9,10]$ in these techniques, the CSWs were modeled as 2D equivalent frames, where rigid members were introduced at the ends of the coupled beams in order to characterize the large size finite widths of the shear walls.

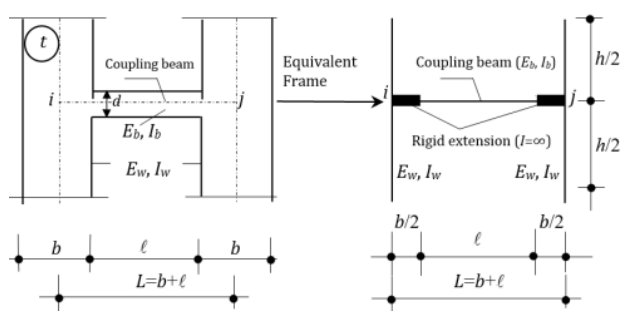

Figure 2. CSW and equivalent frame[12]

Shear walls were represented by beamcolumn elements, while coupling beams were represented by beam elements having rigid ends, as shown in Figure 2, conversely, the coupling beams may be represented by beam elements using stiffness modification factors (Figure 3.). In a modified 2D beam model, the stiffness of a coupling beam is defined as the product of the equivalent stiffness and the stiffness modification factor [11] This finalize technique may be termed as "Magnified Beam Approach".

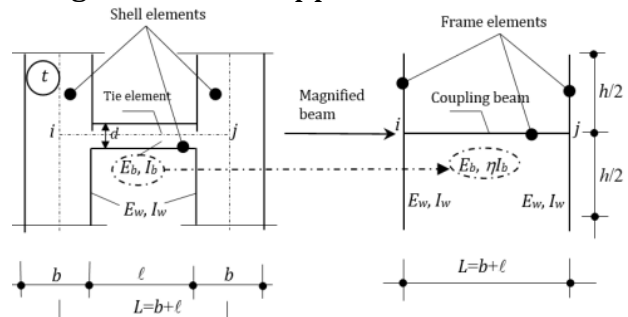

(a)Actual condition (b) Modified condition

Figure 3. CSW and magnified beam [12]

In this technique, the actual rotational stiffness of a coupling beam (Figure 3a; $i$ $j$ member) and the equivalent stiffness of a magnified beam (Figure $3 \mathrm{~b} ; i-j$ member) can be defined as;

$$
k_{i}=\frac{M_{i}}{\theta_{i}}
$$

and

$$
\bar{k}_{i}=\frac{6 E_{b} I_{b}}{L} \frac{L^{2}}{\left(L^{2}+3.9 d^{2}\right)}
$$

where, $M_{i}$ and $\theta_{i}$ are the bending moment and rotation for the section $i$, $E_{b} I_{b}$ is the bending stiffness, $d$ is the gross height of the beam, respectively. On the other hand, the relation between Equations (1) and (2) can be expressed by using a parameter $\eta\left(\eta^{e}=\right.$ elastic or $\eta^{p}=$ plastic) called "stiffness modification factor" as:

$$
k_{i}=\eta \bar{k}_{i}
$$

A simple function for $\eta$ may be used as [11]; 


$$
\eta=a_{0}\left(\frac{h}{\ell}\right)^{a_{1}}\left(\frac{b}{\ell}\right)^{a_{2}}\left(\frac{d}{\ell}\right)^{a_{3}}
$$

or

$$
\eta=a_{0}\left(\frac{h}{\ell}\right)^{a_{1}}\left(\frac{b}{\ell}\right)^{a_{2}}\left(\frac{d}{\ell}\right)^{a_{3}}\left(\frac{\sigma_{c}}{f_{c}}\right)^{a_{3}}
$$

where, the ratios of $h / \ell, b / \ell, d / \ell$ describe the size of openings between the two shear walls and $a_{0}, a_{1}, a_{2}, a_{3}, a_{4}$ are constants, and $\sigma_{c} / f_{c}$ (stress in exciting zones/characteristic compressive strength for the concrete) defines the various stress level which will be suggested by the investigators. For example considering $\sigma_{c} / f_{c} \cong 0.40$, the behavior of the system can be idealized as linear. The actual rotational stiffness of the coupling beam given in Equation 1, may be obtained through detailed finite element analyses (FEAs) using 2D shell elements. In order to evaluate the stiffness modification factor defined by Equation 4, a series of 54 CSWs with varying geometrical parameters of $h=3$ $\mathrm{m}, L=6 \mathrm{~m}, b=3.0,3.2,3.4,3.6,3.8,4.0,4.2$, $4.4,4.6 \mathrm{~m}$, and $d=0.20,0.40,0.60,0.80$, $1.00,1.20 \mathrm{~m}$ were analyzed in elasticplastic stage [11]. By means of a nonlinear regression analysis [13], Equation 4 acquires the final form of;

$$
\eta^{e}=1.921\left(\frac{h}{\ell}\right)^{0.0282}\left(\frac{b}{\ell}\right)^{1.6824}\left(\frac{d}{\ell}\right)^{-0.586}
$$

or

$$
\eta^{p}=1.507\left(\frac{h}{\ell}\right)^{0.0281}\left(\frac{b}{\ell}\right)^{1.6896}\left(\frac{d}{\ell}\right)^{-0.5124}\left(\frac{\sigma_{c}}{f_{c}}\right)^{-0.345}
$$

which correspond to a correlation coefficients of 0.949 and 0.99, respectively.

Such a statistical survey allowed the evaluation of various geometric parameters on the structural behavior of CSWs. The most important parameter for identify the coupling ratio was the height of the coupling beam. Especially for a beam theory algorithm where $d / \ell \leq 1 / 4$, above equations give more reasonable results. Hence, in this study, for various number of storeys $(n=10,20,30$ and 40 ) of the CSWs, all random variables apart from the height of the coupling beam $(d=0,2 \mathrm{~m}-0,6 \mathrm{~m})$ have assumed to be same and then failure probabilities have performed with Monte Carlo simulation (MCS).

\section{Coupling Ratio of a Coupled Shear Wall}

The coupling ratio is a main key parameter defining the behavior of CSWs and should be thoroughly understood before a successful design is performed [6]. It is well known that a CSW reacts to lateral loads at a degree defined by the coupling ratio, $r$. Depending on the value of $r$, the seismic force reduction factor for CSWs may also change as the percentage of the total base overturning moment (Figure 4):

$$
r=\frac{T L}{M_{1}+M_{2}+T L}
$$

where, $L$ is the lever arm between the centroids of the two shear walls, $M_{1}$ and $M_{2}$ are the internal bending moments at the base and $T$ is the axial force in the shear walls representing also the shear forces transferred by the coupling beams. Normally, $T=C$ if the system is symmetric. The bending moment reactions at the base of the walls decrease, since significant portion of the total moment is taken by the coupling action. Since, the $r$ which represents the proportion of the global system overturning moment is a major key parameter in the analysis and design performance of CSWs, it would be highly useful and desirable to provide a good approximation for the estimate of the $r$ in a practical way. 


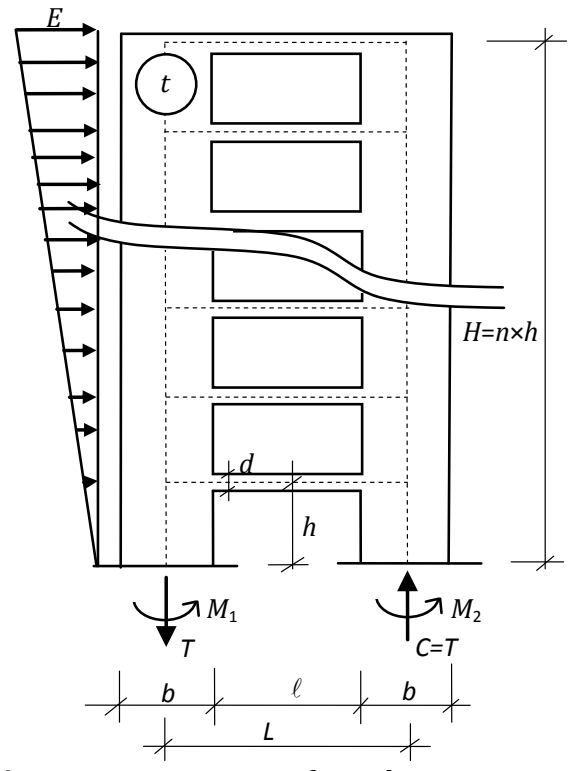

Figure 4. Description of coupling ratio

For example, the $r$-values may be evaluated by using a simplified formula proposed by Chaallal et al. [2];

$$
r=c_{o} \frac{d^{c 1}}{b^{c 2} \ell^{c 3}}
$$

where, $c_{o}, c_{1}, c_{2}$ and $c_{3}$ are constants as given, for various number of storeys, $n$, in Table 1.

Table 1. Constants of equation 7.

\begin{tabular}{|c|c|c|c|c|}
\hline $\boldsymbol{n}$ & $c_{o}$ & $c_{1}$ & $c_{2}$ & $c_{3}$ \\
\hline 10 & 2.324 & 0.512 & 0.462 & 0.509 \\
\hline 20 & 1.463 & 0.265 & 0.281 & 0.190 \\
\hline 30 & 1.295 & 0.193 & 0.223 & 0.106 \\
\hline 40 & 1.190 & 0.145 & 0.188 & 0.059 \\
\hline
\end{tabular}

In a previous study of the first author, the $r$-values have been determined for 216 different cases of coupled shear walls separately, using both equivalent frame analogy and also the magnified beam algorithm as proposed in Section 1.

In that study, the coupled shear wall systems with $n=10,20,30,40$ were analyzed for the geometrical dimensions mentioned before. By using the modification factor, $\eta^{e}$, Equation 7 was expressed as [12]:

$$
r=c_{o} d^{c 1} b^{c 2}\left(\ell \eta^{e}\right)^{c 3}
$$

where, $c_{o}, c_{1}, c_{2}$ and $c_{3}$ are constants as defined in Table 2 .

Table 2. Constants of equation 8

\begin{tabular}{|c|c|c|c|c|}
\hline $\boldsymbol{n}$ & $c_{o}$ & $c_{1}$ & $c_{2}$ & $c_{3}$ \\
\hline 10 & 0.436 & 1.336 & -1.671 & 0.967 \\
\hline 20 & 0.693 & 0.721 & -1.032 & 0.539 \\
\hline 30 & 0.847 & 0.476 & -0.754 & 0.348 \\
\hline 40 & 1.019 & 0.164 & -0.326 & 0.081 \\
\hline
\end{tabular}

$n=$ number of storeys

In the nonlinear regression analysis, $\eta^{e}$ values obtained from finite element analysis were directly used. Furthermore, in Table 3, some important results available in literature $[14,15,16,17,18,19]$, for the coupling ratio values are compared with Equation 7 and proposed Equation 8.

\section{Monte Carlo Simulation}

The MCS is reliability method that is commonly used for structural safety evaluation as a method of exactprobability is explained. Simulation is the process of replication the real world based on a set of assumptions and conceived models of reality. It may be performed theoretically or experimentally. In practice, theoretical simulation is usually performed numerically. As with experimental methods, numerical simulation may be used to obtain simulated data $[20,27$, 28].

For engineering purposes, simulation may be applied to predict or study the performance and/or response of a system. Through repeated simulations, the sensitivity of the system performance to variation in the system parameters may be examined. By this procedure, simulation may be used to appraise 
alternative designs or determine optimal designs.

In this study, MCS has been used to determine the failure probabilities of coupling beam in CSWs. The distributions of the random variables in the performance function are defined in Table 4 . In addition, correlation effects are not taken into account.

Table 3. Constants of equation 8

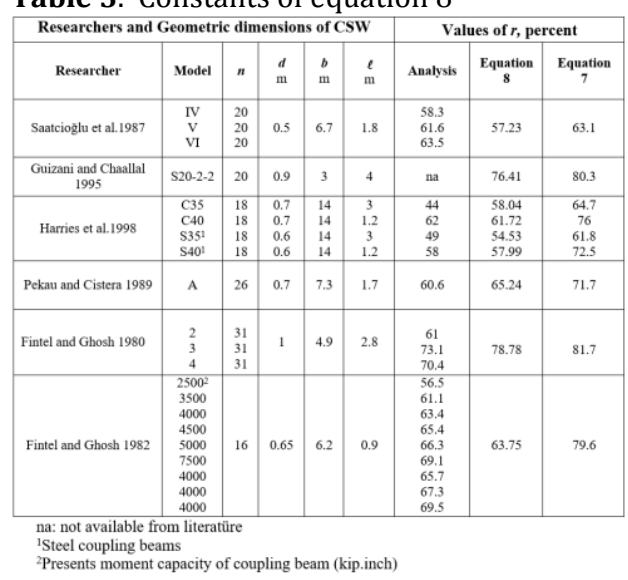

According to MCS, if probability distributions and statistical $\left(m_{i}, \sigma_{i}\right)$ of the random variables $\left(X_{i}\right)$ in the performance function $Z=g(X)$, are defined, random numbers for each of these random variables may be generated. By substituting the sets of these random numbers into performance function, sample of the function is formed, and the failure probability $p_{F}$ is determined. Shortly, this approach is a random sampling method which generates the random numbers using a computer program.

\subsection{Simulation procedure}

In this chapter, the failure probabilities of the coupling beams (Figure 4) will be defined and calculated using MCS [21, 22, $23,24]$. When the design shear force of coupling beam exceeds nominal shear force, it is assumed that the coupling beam has been collapsed. Thus, the performance function may be expressed as:

$$
Z=g(X)=V_{n}-V_{d}
$$

According to ACI/318-2000 [25], the nominal shear force of coupling beam in Equation 9 can be written as:

$$
V_{n}=b_{w} d\left(\alpha_{c} \sqrt{f_{c}^{\prime}}+\rho_{n} f_{y}\right) \text { for } \ell / d \geq 4
$$

$$
V_{n}=(5 / 6) \sqrt{f_{c}^{\prime}} b_{w} d \text { for } \ell / d<4
$$

where, $V_{d}$ is the design shear force, $f_{c}^{\prime}$ is the compressive strength of concrete, $f_{y}$ is the yield strength of reinforcement, $b_{w}$ is wide of the section, $d$ is the effective depth, $\rho_{n}$ is the ratio of reinforcement, finally $\alpha_{c}$ is the coefficient defining the relative contribution of concrete strength to nominal wall strength.

In Eq.10, $\left(\alpha_{c}=1 / 4\right.$ for $\left.d / \ell \leq 1.5\right)$, ( $\alpha_{c}=1 / 6$ for $\left.d / \ell \geq 2.0\right), \alpha_{c}=(1 / 6$ $\sim 1 / 4$ ) for $1.5<d / \ell<2$, and $\rho_{n}=0.0025$ have been considered.

The design shear force determined by using the method proposed this study may be expressed as:

$$
V_{d}=\frac{r h V_{\text {base }}}{n L}
$$

where $V_{\text {base }}$ is the base reaction. Here, $r$ may be evaluated by using Equation 8 . Thus, Equation 9 must contain following random variables:

$$
Z=g(X)=g\left(f_{c}, f_{y}, b, d, \ell, V_{\text {base }}\right)
$$

Means $m_{i}$, coefficients of the variations $V_{i}$, and the probability distributions of the random variables are given in Table 4. Analysis is performed for $n=10,20,30$ and 40 storeys, and $d=0.2,0.4,0.6 \mathrm{~m}$, separately. For structures having different storey levels, statistical data concerning with all random variables are assumed as an identical except for the beam height, $d$. Besides, $b_{w}, h, \rho_{n}$ are 
assumed to be deterministic variables and values of the $b_{w}, h, \rho_{n}$ are taken as $0.30 \mathrm{~m}, 3 \mathrm{~m}$ and 0.0025 , respectively.

All random variables are assumed to be statistically independent. In simulation procedure, the sample size, $n$, is taken 1.000.000 [26]. Furthermore the failure probabilities of the coupling beam have been performed with a computer program using MCS.

Table 4. The failure probabilities for different number of storeys and coupling beam heights

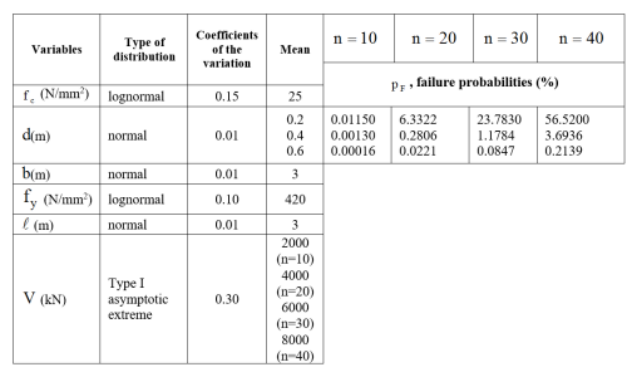

\section{Conclusions and Remarks}

This paper aims to investigate the failure probabilities of $\mathrm{R} / \mathrm{C}$ CSWs considering the coupling ratio numerically. Based on the results of analysis, the following conclusions are obtained:

1. The coupling ratio of laterally loaded CSWs of a $\mathrm{R} / \mathrm{C}$ high rise building can be calculated successfully by using the equivalent frame analogy in conjunction with the stiffness modification factors of the coupling beams.

2. The resulting formulations enable the engineer to determine the internal forces and deflections of the building with CSWs, without the necessity of conducting a complete structural analysis. As seen in Equation 8, the most important parameter for identify the coupling ratio is the height of the coupling beam. For this reason, failure probabilities have been performed with MCS for various number of storeys $(n=10,20,30$ and 40) of the CSWs, varying the height of the coupling beams. As the values of " $d$ " increase, the " $p_{F}$ " values decrease or as the values of " $d$ " decrease, the " $p_{F}$ " values increase, as expected.

\section{References}

[1] Pala S, Özmen G. Effective Stiffness of Coupling Beams in Structural Walls, Computer and Structures 54(5): 1995, pp.925-931.

[2] Chaallal O, Gauthier D. Malenfant P. Classification Methodology For Coupled Shear Walls, Journal of Structural Engineering, ASCE 122(12): 1996, pp.1453-1458.

[3] Tezcan SS, Kaya ZD. The Effective Rigidity of a Coupled Shear Wall. Bogazici University, Department of Civil Engineering, Vedat YerliciEngineering and Education, A Volume Honoring Prof.Dr. Vedat Yerlici, Istanbul, 1997, pp.361-370.

[4] Harries KA, Gong B, Shahrooz BM. Behavior and Design of Reinforced Concrete, Steel, and Steel-concrete Coupling Beams, Earthquake Spectra 16(4): 2000, pp.775-799.

[5] El-Tawil S, Kuenzli CM. Pushover of Hybird Coupled Walls. I: Analysis and Behavior, Journal of Structural Engineering, ASCE 128(10): 2002, pp.1282-1289.

[6] El-Tawil S, Kuenzli CM, Hassan M. Pushover of Hybird Coupled Walls. I: Design and Modeling, Journal of Structural Engineering, ASCE 128(10): 2002, pp.1272-1281.

[7] Hassan M, El-Tawil S. Inelastic Dynamic Behavior of Hybird Coupled Walls, Journal of Structural Engineering, ASCE 130(2): 2004, pp.285-296.

[8] Kent A, Harries et al. Parametric Study of Coupled Wall Behavior- 
Implications for the Design of Coupling Beams, Journal of Structural Engineering 130(3): 2004, pp.480-488.

[9] Xilin-L, Yuantao C. Modeling of Coupled Shear Walls and Its Experimental Verification, Journal of Structural Engineering 131(1): 2005, pp.75-84.

[10] Wan-Shin P, Hyun-Do Y, Jae-Yong C, Yong-Chul K. Experimental studies on seismic behavior of steel coupling beams, Structural Engineering and Mechanics, Techno Press Journal 20(6), 2006.

[11] Doran B. Elastic-Plastic Analysis Of R/C Coupled Shear Walls : The Equivalent Stiffness Ratio of The Tie Elements, Indian Institute of Science 83: 2004, Pp.87-94.

[12] Doran B. A Magnified Beam Algorithm To Determine The Coupling Ratios of R/C Coupled Shear Walls. Struct. Design Tall Spec. Build. 18 (8): 2009, Pp.921-929.

[13] Wadsworth HM. Handbook of Statistical Methods for Engineers and Scientists. McGrawHill Inc, NewYork, 1997.

[14] Saatcioglu M, Derecho AT, Corley WG. Parametric Study of EartquakeResistant Coupled Walls. ASCE Journal of the Structural Division 113(1): 1987, pp.141-157.

[15] Guizani L, Chaallal O. Demande en Ductilité des murs de Refend Couplés. Proceeding of the Seventh Canadian Conference on Earthquake Engineering, Montreal, 1995, pp.461-468.

[16] Harries KA, Mitchell D, Redwood RG, Cook WD. Seismic Design and Analysis of Prototype Coupled Wall Structures. Canadian Journal of Civil Engineering 25(5): 1998, pp.808818.
[17] Pekau OA, Cistera V. Behaviour of Nonlinear Coupled Shear Walls with Flexible Bases. Canadian Journal of Civil Engineering 16(1): 1989, pp.45-54.

[18] Fintel M, Ghosh SK. Seismic Resistance of a 31 Storey WallFrame Building Using Dynamic Inelastic Response History Analysis. Proceeding of the Seventh World Conference on Earthquake Engineering, Istanbul, 1980, pp.379386.

[19] Fintel M, Ghosh SK. Case Study of Aseismic Design of a 16-story Coupled Wall Using Inelastic Dynamic analysis, ACI Journal 79(3): 1982, pp.171-179.

[20] Ang A, Tang WH. Probability Concepts in Engineering Planning and Design, V.II, Decision, Risk, and Reliability, Wiley, New York, 1984.

[21] Jorge EH. An examination of methods for approximating implicit limit state functions from the viewpoint of statistical learning theory, Structural Safety 26: 2004, pp.271-293.

[22] Yong L, Xiaoming Gu. Probability analysis of RC Members deformation limits for different performance levels and reliability of their deterministic calculations, Structural Safety 26: 2004, pp.367389.

[23] Christopher DE, Michel T, Zhenyu L. Evaluation of accuracy and efficiency of some simulation and sampling methods in structural reliability analysis, Structural Safety 27: 2005, pp.356-392.

[24] Lars T. Proban-probabilistic analysis, Structural Safety 28: 2006, pp.150-163.

[25] ACI 318, Building Code Requirements for Structural Concrete, American Concrete 
B.DORAN vd. / Bağ Kirişlerinin Göçme Olasılıklarının Monte Carlo Simülasyonu ile Belirlenmesi

Institute, Farmington Hills, MI, 2011.

[26] Nowak AS, Collins KR. Reliability of Structures, (1st Edition), McGrawwHill, Singaporei 2012.

[27] Öztekin E. Reliabilities of distances describing bolt placement for high strength steel connections, Structural Engineering And Mechanics, 54(1), 149-168., Doi: 10.12989 /sem.2015.54.1.149, 2015.

[28] Öztekin E. Cıvatalı Çelik Yapı Birlesimlerinde Civata Yerlesim Mesafelerinin Güvenilirliklerinin MCS Metodu İle Arastirılması. Pamukkale Üniversitesi Mühendislik Bilimleri Dergisi, 21(6), 213-223. Doi: $\quad 10.5505 /$ pajes.2015.29981, 2015. 